\title{
Relationship Between Trade Balance and Real Exchange Rate (Marshal Lerner Condition): Evidence from Pakistan
}

\author{
Syeda Hina Nawaz \\ M. Phil Economics \\ Department of Economics, Islamia University of Bahawalpur
}

\begin{abstract}
The study analyzed the Marshal Lerner Condition implementation in Pakistan from the year 1961 to 2013, data gathered from the State Bank, World Bank and IMF statistics. We find the relationship between the trade balance and real exchange rate in Pakistan. On the annual time series data for the years 1961-2013 we used unit root test for stationarity, and johansen's cointegration test for long-run equilibrium relationship between the variables for each model. The central outcomes of this study are: long run relationship exists between trade balance and exchange rate, these relationships are explaining that exports significantly affect with the exchange rate in shortrun and in long-run also. The long run relationship also exists and devaluation of the currency improve the trade balance by increasing the exports and decreasing the imports.
\end{abstract}

Keywords: Exchange rate, Trade balance

DOI: $10.7176 / \mathrm{JESD} / 11-7-01$

Publication date: April $30^{\text {th }} 2020$

\section{Introduction}

Marshal Lerner condition is at the center of the elasticity's approach to the balance of payment, it is also called the Marshal Lerner Robinson after Marshal Lerner Condition. Its named is due to the three economists who independently discovered it Alfred Marshal (1842-1924), Abba Lerner (1903-82) and John Robinson (190383).The main questions of condition one following when a real devaluation or real depreciation of the currency improves the country current account balance. Its means that trade in services, investment, income flows and unilateral transfers are equal to zero. So current account is equal to trade account .With the devaluation of a currency will improve the trade balance, If the sum of the elasticity's of the demand for exports and imports with respect to the real exchange rate is greater than one (ling et al,2006). The issue of whether an alteration in exchange rate will improve position of the trading of the country has been remained Center to the consideration of policymakers for a long time. That idea was not only important during the gold standard period but also fixed exchange rate regime. It still leftovers important to policymakers who think that a change in exchange rate, such as devaluation, will promote their export industries. Policymakers are concerned in the effects of relative price fluctuations on trade flows. These conditions beneath which a depreciation or devaluation of currency can progress a country's trade balance as provided under the Marshall-Lerner condition. In 1982 the main move occurred in Pakistanis exchange rate policy by replacing managed floating to fixed and floating exchange rate system and another brave step was that Pakistan's rupees was delinked from the US dollar. The changeability of year to year all the same the average years share of 4 main trading partners of Pakistan i.e. UK, Japan, Germany, and USA has been remained in the range of 31-39 during 1980 -95. During the time period, these countries accounted for an average of $68 \%$ trade deficit of Pakistan. Moreover export commodity modification remains feeble. The center of phenomena is the efficiency of real depreciation (Fouzia and Akhter 2000).

Hassan and khan (1994) has been claimed that during 1972 to 1991 depreciation of currency positively affect the economy of Pakistan so Marshal Lerner condition also applied to improve the export and import demand elasticities, Bahmani-Oskooee (1998), applied cointegration from the period (1973 to 1990) and reported that the ML condition was strongly satisfied for the case of the Pakistan. Others are, Malik and Akhter (2000) used quarterly data and find the ML conditions with Pakistan's 4 trading trade balance. Aftab and Khan (1995) used quarterly data (1983-93) to find the the sum of import and export elasticity for marshal lerner condition and concluded the existence of marshal lerner condition in Pakistan.

Many observed analyses, in econometric models applied and multi-country panel regressions to individual countries have been directed into how exchange rate changes affect the trade balance of developed countries and developing countriesThere are also some studies which summarized that there was no confirmation in support of the Marshall-Lerner condition. Since 1982 the Pakistan rupee has been characterized by a managed float; the rupee was attached to a basket of currencies with the US dollar being the main presenter currency. In 2000 July that system was changed by a free float. However, we can discuss that in exercise regular State Bank of Pakistan interference continues, and therefore the problems of real depreciation to correct the balance of trade still remain applicable. In this paper investigate that if the Marshall-Lerner condition holds true for Pakistan in the long run and short run. Purpose of the study is to investigate the long-run performance of real exchange rate, imports, and exports of Pakistan. We shall also investigate that in the short run, whether there is an adjustment towards the 
equilibrium path in response to a sudden shock. Does Marshal Lerner condition holds in the case of Pakistan? Find out the relation between the real exchange rate and balance of trade. To find out that devaluation of Pakistan rupee affect the balance of trade. To find out the relationship between the imports, exports and real exchange rate in the case of Pakistan. Liberalization effect on economy. In that research the main cause of its importance is to revise the study on Marshal Lerner condition.

\section{Literature Review}

Exchange rate policy is one of the utmost important issues in the reaction of the trade balance to the real exchange rate. The effects of currency depreciation on a country's trade balance have been extensively examined in the empirical literature in the context of the Marshall Lerner condition. There are some reviews which show the existing literature on the Marshal Lerner condition.

Fouzia and Akhter (2000), attempted trade performance with its major trading partners of Pakistan from 1982 to 1996 . . So the results shows that $1 \%$ increase in trading partners' income give $5 \%$ increase in our exports.

Afzal (2001), explored the imports functions for Pakistan with simultaneous equations approach. The main objective of that study was to see the influence of liberalization effort from onward from 1960 to 1999 . Trade liberalization was not good for the imports, but also crucial. Sustainment of real effective exchange rate under a regime of liberal trade has been increased the importers value but not the imports volume.

Arize (2002), attempted to estimate the imports and exports in 50 countries and structural breaks with the help of cointegration test, by using quarterly data from 1973:2 to 1998:1. The author used multivariate cointegration technique and full information maximum likelihood estimators. The results show that most of the countries were short run phenomena and in long run they are sustainable.

Aftab and Aurangzeb (2002), analyze the long run and short run impact of currency devaluation on Pakistan's trade performance by using quarterly data, from 1980- 2002, So, they proved that sum of export and import demand were greater than 1. Which satisfied the Marshal Lerner condition in the case of Pakistan for long run.

Qadir and Kemal (2005), attempted to estimate real exchange rate, import and export movements which was called a trivariate analysis from December 1981 to 2003 January which show the relationship between them for the long run but they concluded that devaluation may improve balance of trade but during (2011) due to remittances and high inflow of foreign exchange give strength to the Pakistani rupee.

Majeed et al (2006), described the determinants of exports in developing countries. They gathered data from over the period 1970 -2004 of 75 developing countries from sample of 155 countries .Evidence shows that a sustainable growth patterns promotes exports.

Afzal and Shah (2006), used 3SLS to investigate the responsiveness of exports demand and supply to nominal, real and effective exchange rates for the period 1972-2005. They reported that liberalisation of the trade regime leads to depreciation and its impact is positive on export demand and supply. When economy is liberalized, export incentives and subsidies assume relatively more importance to promote exports. Due to low supply price elasticity, exchange rate changes are not the sufficient condition. In addition to exchange rate, other factors also matter. Maintenance of a reasonably realistic exchange rate is expected to help export promotion and will have healthy impact on income distribution and employment.

Kakar, et al (2010), explored to estimate the determinants of Pakistan's trade balance with ARDL (cointegration) technique in the long run and short run which means that with the help of depreciation, trade balance has been improved in short run and also in long run. The results show strong relationship between Trade Balance and Income (GDP), money supply, exchange rate. These factors improve the Trade balance in the case of Pakistan, so Marshal Lerner condition exists in Pakistan.

Afzal (2011), examined the impact of fiscal and monetary policies on economic growth of Pakistan. The study noted that since the de-linking from USA dollar in January 1982, using cointegration technique, it has been found that these policies have stable and long- run relationship with the domestic output

In all the research work we cannot find the research on Marshal Lerner condition for Pakistan till 2013 from the period 1960; due to structural changes, devaluation of currency and after liberalization in Pakistan there are many changes come in the economy. Mostly writers' works on quarterly data and Pakistan relation with other countries. So i want to revisit the condition for Pakistan on yearly data. It is important to see the significant effect of the devaluation in the long run.

\section{Research Strategy and Methodology}

This section discusses the methods and techniques to find out import and export relationship with relate to Marshal lerner condition.

\section{Data and Sample Size}

The data was gathered from 1960 to 2013 .The data on real world income data have been taken from world tables and the data on imports have been taken from the Pakistan Economic Survey (various issues).the data on exports were gathered from the Hand book of Statistics on Pakistan economy. The data regarding world wholesale price 
Index (WPI) and unit value of imports in domestic currency have been taken from International Financial Statistics (IFS) yearbooks (various years).GDP of statistics was find from the World Development Indicators (WDI) April 2015.The data on CPI of US was find from The World Bank.Pakistan GDP (PPP) was found from World Bank, International Comparison Programmed Data base. GDP of different countries was gathered from World Bank National Accounts Data and OECD National Accounts data files.

\section{Model Specification}

The principal objective of this study is to re-examine the Marshall-Lerner (ML) condition for Pakistan over the period 1961-2013. The effects of devaluation or depreciation on the trade balance of a country are usually examined by the Marshall-Lerner (ML) condition, which states that if the sum of the absolute values of imports and exports demand price elasticities is greater than one, devaluation is expected to improve the trade balance of a country. Ml condition could be examined by exploring the imports and exports behavior of a country.

The degree of openness of a country is indicated by the ratio of imports and exports to GDP of that country. Pakistan embarked on trade liberalisation programme in 1990s that has also been followed today. The examination of exports and imports trends show that though exports have increased, however, imports have increased in value terms resulting in current account deficit due to frequent devaluation of Pak rupee. Therefore, study of both imports and exports is extremely desirable in order to have a pragmatic picture of the foreign trade situation as that will help in finding the ML condition. Moreover, exchange rate policy has become an important element of the traditional stabilisation programme to improve external balance and for investigating the traditional MarshallLerner condition to see the impact of devaluation on trade balance.

Afzal (2004a) has reported that Structural Adjustment Reforms were started with the help of IMF and World Bank in 1982-83 having the objective of improving the efficiency of the economy by increasing the role of the private sector. The reforms included the delinking of the rupee from US dollar in January 1982, price deregulation of a large number of products, denationalization of industry, imports liberalization and export expansion. He also mentions that the unwillingness to use devaluation has been a constant bone of contention in the negotiations between the governments of some developing countries and the IMF. During 1970s IMF emphasis on devaluation was not much strong. However, in 1980s IMF attitude towards currency depreciation became very stringent. There is considerable disagreement among theoreticians concerning the desirability of devaluation in developing countries. The advocates argue that it is a priceless instrument for strengthening the balance of payments (BoPs) because of its impact on absolute prices and real and monetary variables. Whereas, critics argue that devaluation is stag factionary, reducing real output and increasing domestic rate of inflation and fails to improve the current account of the BoPs.

Khan (1974) found that for most of the 15 developing countries including Pakistan in his sample showed price elasticities of both import and export demand were close to or greater than one. This implies that the ML condition for successful devaluation would be easily satisfied in a number of developing countries including Pakistan for the period 1951-1969. Arize (1986) reported that the Marshall-Lerner condition for devaluation was satisfied for a majority of countries in his sample that included nine African countries for the period 1960-1982. Hasan and Khan (1994) have examined the impact of devaluation on Pakistan's trade balance for the period 1972 91. They have reported that Marshall- Lerner condition for devaluation is satisfied for Pakistan and thus devaluation will be successful in improving the trade balance. The absolute sum of exports (-1.32) and import demand elasticities (-0.35) adds up more than one (Afzal 2001a, 2001b). These studies are relatively old and there is need to revisit the ML condition to see its significance for foreign trade.

According to Afzal (2004b) during 1950s and 1960s most developing countries including Pakistan opted for vigorous industrialization through Import Substitution (IS). In the following decades (1970s, 1980s) a mix policy of export-promotion and import-substitution was pursued in Pakistan. During 1990s import-liberalization and export-promotion policies have been followed in Pakistan. Therefore, study of the impact of liberalization efforts on both imports and exports is desirable.

\section{a. Model I: Import Demand Equation}

Khan (1974) has used the traditional import demand model and Afzal (2001) added the liberalization dummy. The current study also adds population growth another important factor that is supposed to affect imports significantly since as population grows demand for both domestic and foreign goods also increases. Therefore, following Khan (1974), Hasan and Khan (1994) and Afzal (2001b), following equation is specified in log-linear form for import demand:

$\operatorname{lnMd}=\varphi_{0}+\varphi_{1} \ln (\mathrm{uvmp} / \mathrm{wpi})+\varphi_{2} \operatorname{lny}+\varphi_{3} \ln \mathrm{pop}+\varphi_{4} \ln r \mathrm{ex}+\varphi_{5} \mathrm{Do}_{0}$

Since the equation has been described in logarithm, the coefficients $\varphi_{1}, \varphi_{2}, \varphi_{3}$ and $\varphi_{4}$, are respectively relative price for imports, real GDP, population and real exchange rate elasticities. The expected signs of the coefficients in equation (3.1) are: $\varphi_{1}<0, \varphi_{2}>\varphi_{3}>0, o$ and $\varphi_{4}>0$ and the sign of $\varphi_{5}$ is uncertain because it is difficult to say something with certainty about the positive or negative effects of liberalisation on imports.

Where

i. $\ln =$ natural logarithm 
ii. $\mathrm{Md}=$ real value of imports demand

iii. uvmp = unit value of imports of Pakistan,

wpi $=$ wholesale price index (wpi) of Pakistan

$$
\text { 1. } \mathrm{y}=\text { real GDP of Pakistan }
$$

rex = real exchange rate

Real exchange rate is defined as

rex $=$ ner $*$ cpi/USA wpi $_{\text {in }}$

ner = nominal exchange rate

cpi = domestic price deflator, for example CPI

$\mathrm{US}_{\mathrm{WPI}}=$ deflator for the foreign price level
Do

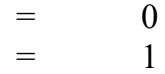
1960 to 1990
$1 \quad 1991$ to 2013

\author{
(post liberalisation)
}
(before- liberalisation]

Model II: Export Demand

The demand for exports depends on the world or important trade partners' income world economic conditions represented by the US income, real exchange rate and also on the competition of domestic export prices with the world or important trade partners export prices represented USA unit value of exports.CPI has been added to account for inflation and its effects on the domestic economy, imports and exports, so this variable is also added. Therefore, following Afzal (2001b) and Afzal and Shah (2006) in log-linear form, demand equation for exports is specified with modification.

\section{$\ln x_{d}=\beta_{0}+\beta_{1} \ln \left[\right.$ uvxp/uvxUSA $+\beta_{2} \ln U S y+\beta_{3} \ln r e r+\beta_{4} \operatorname{lncp} p_{i}+\beta_{5} D_{0}$}

Where

$\mathrm{x}_{\mathrm{d}} \quad=$ real value of exports demanded

uvxp = Unit value of exports of Pakistan in US dollars

$\mathrm{uvX}_{\mathrm{USA}}=$ Unit value of exports of US

$\mathrm{Us}_{\mathrm{y}} \quad=\mathrm{US}$ income

rex $=$ real exchange rate defined in Import model

$\mathrm{D}_{0} \quad=0 \quad 1960$ to $1990 \quad$ (before - liberalisation)

$=11991$ to $2013 \quad$ (post-liberalisation)

Since the equation is specified in logarithm, the coefficients are elasticities in the equation. $\beta_{1}$ is relative price, $\beta_{2}$ is USA income elasticity and $\beta_{3}$ is real exchange elasticity respectively. The expected signs of the coefficients are positive. Nothing can be said a priori about $\beta_{4}$ because trade liberalisation may have positive or negative effects on exports.

\section{Unit Root Test}

Since time series data will be used, it is necessary that time series properties are explored. A time series is stationary if its mean, variance and covariance are time invariant. A time series which is stationary after being differenced once is said to be integrated of order 1 and is denoted I (1). In general a series, which is stationary after being differenced d times, is said to be integrated of order $d$, and denoted as I (d). A series that is stationary without differencing is said to be I (0). This definition assumes that $d$ is an integer. A series which is I (1) is said to have a unit root and a series which is I (d) has d unit roots. It is an empirical fact that many important macroeconomic variables appear to be integrated of order 1 .

Dickey-Fuller (DF) Tests

Dickey and Fuller have used three different regression equations to test for the presence of a unit root.

$\Delta \mathrm{Y}_{\mathrm{t}}=\lambda \mathrm{Y}_{\mathrm{t}-1}+\mu_{\mathrm{t}}$

$\Delta \mathrm{Y}_{\mathrm{t}} \quad=\quad \alpha_{0}+\lambda \mathrm{Y}_{\mathrm{t}-1}+\mu_{\mathrm{t}}$

$\Delta \mathrm{Y}_{\mathrm{t}}=\alpha_{0}+\alpha_{1 \mathrm{t}}+\lambda \mathrm{Y}_{\mathrm{t}-1}+\mu_{\mathrm{t}}$

The difference between the above regressions results from the presence of the deterministic elements $\alpha_{0}$ and $\alpha_{1 t}$. The first is a pure random walk, second is random walk with drift or intercept and the third includes both drift and linear time trend. In all the above regression equations the parameter of interest is $\lambda$. If $\lambda=0, Y_{t}$ has a unit root. The test involves estimating on or more of the above equations using OLS in order to get the estimated value of $\gamma$ and associated standard error.

The estimation methodology is the same for the above three forms of equations. The critical values of the tdistribution depend on whether an intercept and/or time trend is included in the regression equation. Dickey and Fuller (1979) found that the critical values for $\gamma=0$ depend on the form of the regression and sample size. These statistics are denoted as $\boldsymbol{\tau}, \boldsymbol{\tau}_{\mu}$, and $\boldsymbol{\tau}_{\tau}$ are the appropriate statistics to use for equations 3.3, 3.4 and 3.55 . To determine whether to accept or reject the $\mathrm{H}_{0:} \gamma=0$, the resulting t-statistics can be compared with the values reported in Dickey and Fuller (1976) tables. However, these tables are not totally adequate and MacKinnon (1996) has considerably extended these tables. If the computed $\tau<\mathrm{DF}$ or MacKinnon DF critical values then we do not reject the hypothesis that the given time series is stationary. If less than the critical values, the time series is non-stationary. If the error term is auto-correlated in the above equations, these equations can be modified as 
follows:

$\begin{array}{lll} & \text { ii. } & \text { without any constant and trend } \\ \Delta \mathrm{Y}_{\mathrm{t}} & =\lambda \mathrm{y}_{\mathrm{t}-1}+\beta_{1} \sum \Delta \mathrm{Y}_{\mathrm{t}-1}+\mu_{\mathrm{t}} \\ & \text { iii. } & \text { with constant but no trend } \\ \Delta \mathrm{Y}_{\mathrm{t}} & = & \alpha_{0}+\lambda \mathrm{y}_{\mathrm{t}-1}+\beta_{\mathrm{I}} \sum \Delta \mathrm{Y}_{\mathrm{t}-1}+\mu_{\mathrm{t}} \\ & \text { iv. } & \text { with constant and trend } \\ \Delta \mathrm{Y}_{\mathrm{t}} & =\alpha_{0}+\alpha_{2 \mathrm{t}}+\lambda \mathrm{y}_{\mathrm{t}-1}+\beta_{\mathrm{I}} \sum \Delta \mathrm{Y}_{\mathrm{t}-1}+\mu_{\mathrm{t}}\end{array}$

When DF test is applied to above models, it is called Augmented Dickey-Fuller (ADF) test. The test estimates one or more of the above equations using OLS to accept or reject Ho: $\lambda=0$ by using Dickey- Fuller tables. The convential t-statistic given in standard $t$ table cannot be used because the left-hand variable is non-stationary. More recently, MacKinnon (1996) has a much larger set of replications than those underlying Dickey-Fuller tables. This study uses the MacKinnon (1996) critical values. As ADF test is based on the assumption that the variable follows a simple first-order auto regression and the disturbance term is independently and identically distributed (i.i.d), an examination of the residuals from above regressions often demonstrates that the problem of serial correlation is widespread. To deal with this problem lagged values of the dependent variables are entered in the regression until the residuals are white noise. A criterion for the number of lags to be entered is the $\mathrm{t}$-test for the last difference of the variable (Enders 2004, Gujarati and Sangeeta 2007).

The general requirement for applying the co-integration technique is to have variables of the same order of integration at hand. Therefore, the following three steps are necessary: (a) determination of the order of integration (b) formulation of co-integration models, and (c) construction of Error-Correction Models.

\section{The Johansen Cointegration Test}

Engle-Granger procedure has three attributes that make it a popular technique:(1) the applicability of OLS (2) the cointegration parameters can be estimated separately from the dynamics of the process (3) the favourable asymptotic properties of this procedure that is super-consistency and variance minimising estimation of cointegration vectors. However, it also suffers from the following drawbacks.

First, the large sample properties on which the test is based may not be applicable to the sample sizes usually available to the economists. In practice it is possible that one regression indicates cointegration whereas reversing the order indicates no cointegration. This is an undesirable feature of the test, because the test for cointegration should be invariant to the choice of variables. In case of three or more variables the problem becomes more difficult.

Second, in testing for three or more variables, there may be more than one cointegrating vector. The method has no systematic procedure for the estimation of the multiple cointegrating vectors. Third, it is based on a twostep estimator. Thus error introduced in one step is carried into second step. Thus, Engle-Granger test yields consistent long run coefficients but biased standard errors (Enders 2004). Keeping in view these drawbacks, we will expand the analysis by introducing Johansen's technique that simultaneously looks at all variables and this can serve as a criterion for interpreting the results obtained by the Engle-Granger procedure (Afzal and Ejaz 2010).

The Johansen's technique for estimating cointegration is said to be superior because it is based on Maximum Likelihood procedure that provides test statistics to determine number of cointegrating vectors as well as their estimates. Therefore, we use Johansen $(1991,1995)$ technique. The Johansen's technique is a multivariate generalisation of the Dickey-Fuller test. The Maximum Likelihood procedure tests how many of the cointegration vectors are significant that is what rank the cointegration matrix has.

Consider a VAR of order $\mathrm{p}$.

$$
\mathrm{Y}_{\mathrm{t}}=\mathrm{A}_{1} \mathrm{Y}_{\mathrm{t}-1}+\mathrm{A}_{2} \mathrm{Y}_{\mathrm{t}-2 \ldots} \ldots+\mathrm{A}_{\mathrm{p}} \mathrm{y}_{\mathrm{t}-\mathrm{p}}+\mathrm{BZ}_{\mathrm{t}}+\mu_{\mathrm{t}}
$$

Where $Y_{t}$ is a k-vector of non-stationary $\mathrm{I}(1)$ variables, $Z_{t}$ is a d-vector of deterministic variables, and $\mu_{t}$ is a vector of innovations. We can write the VAR as

$$
\Delta \mathrm{Y}_{\mathrm{t}}=\Pi \mathrm{Y}_{\mathrm{t}-1}+\sum_{i=1}^{p-1} \Gamma \mathrm{i} \Delta \mathrm{Y}_{\mathrm{t}-\mathrm{i}}+\mathrm{BZ}_{\mathrm{t}}+\mu_{\mathrm{t}} \sum_{\text {Where } \Pi=\sum_{i=1}^{p} \mathrm{Ai}-\mathrm{I} \quad \mathrm{i}=1 \ldots \mathrm{p} \Gamma \mathrm{i}=-\sum_{j=i+1}^{p} \mathrm{~A}_{\mathrm{j}}}
$$

Where $\Delta$ is difference operator and $\mathrm{I}$ is a $\mathrm{k} \cdot \mathrm{k}$ identity matrix.

Johansen estimates the rank of the matrix $\Pi$ that is the rank of the coefficient matrix of the lagged variables in levels. The rank of coefficient matrix $\Pi$ determines the number of cointegrating vectors because the rank of $\Pi$ is equal to the number of independent cointegrating vectors.

Johansen method uses two test statistics for the number of cointegrating vectors: the Trace test and Maximum Eigenvalue $(\lambda$-max) test. The two test statistics are:

$\lambda$ trace $(\mathrm{r}) \quad-\quad \mathrm{T} \sum \operatorname{Ln}[\mathrm{I}-\lambda \mathrm{I}]$ 
$\lambda \max (\mathrm{r}, \mathrm{r}+1) \quad=\quad-\mathrm{T} \operatorname{Ln}[\mathrm{I}-\lambda \mathrm{I}]$

Where: $\hat{\lambda}=$ the estimated values of the characteristic roots (also called Eigenvalues) obtained from the estimated $\Pi$ matrix,

$\mathrm{T}=$ number of useable observations.

$\lambda$ trace tests the null hypothesis (Ho) that the number of distinct cointegrating vectors is less than or equal to $r$ against a general alternative. The second statistic $(\lambda \max )$ tests Ho that the number of cointegrating vectors is $r$ against the alternative of $r+1$ cointegrating vectors. Johansen and Juselius (1990) have provided the critical values of the $\lambda$ trace and $\lambda \max$ statistics. Given the above-noted problems with EG cointegration test, Johansen's procedure is currently the most reliable test for cointegration and has better small sample properties. The advantage of the Johansen's procedure is that several cointegration relationships can be estimated simultaneously. But there are also two problems associated with Johansen's procedure (a) The short run dynamics of a system and the significance of the single variables cannot be modelled like in error-correction (2) The economic interpretation of a multivariate cointegration model becomes difficult. Testing only models for cointegration that has been found significant in the single-equation case can lessen the problem of interpretation (Afzal and Ejaz 2010).

However, this relationship may be disturbed by short run deviations from equilibrium and thus an error correction model (ECM) may be an appropriate framework that is an extension of the Granger causality test where an error correction term is introduced into the test. If variables are cointegrated then an ECM exists which combines the long run relationships with the short run dynamics of the model known as Granger's representation theorem.

\section{Result and Discussion}

In that section we discussed the results of our estimated models to investigate the nature and long run relation relationship, between import and export as dependent variables, depend upon different variables. We applied first of all OLS but it show significant results but then, we want to find the unit root test for stationarity and then applied johansen co-integration model .Now these results are discussed below.

Table 4.1 OLS Results Imports Function:

\begin{tabular}{|l|l|l|l|l|}
\hline Variable & Coefficient & Std.Error & t-statistic & p-value \\
\hline Constant & -34.02605 & 8.901024 & -3.822711 & 0.0004 \\
\hline Ln income & 0.643388 & 0.166391 & 3.866736 & 0.0004 \\
\hline Ln relative price of import & -0.228917 & 0.087123 & -2.627513 & 0.0117 \\
\hline Ln real exchange rate & 0.492679 & 0.158218 & 3.113922 & 0.0032 \\
\hline Ln population & 2.969111 & 0.958395 & 3.098005 & 0.0034 \\
\hline D0 & 0.034448 & 0.175683 & 0.196079 & 0.8454 \\
\hline
\end{tabular}

$\mathrm{R}^{2}=0.99$ Durbin-Watson $=0.81$, F-statistic: $827.56(0.000)$

Table 4.1 shows OLS (Ordinary Least Squares) results for imports function. The coefficients have correct and expected signs. Domestic income, relative price of imports (UVMp/WPI), and real exchange rate are positive and significant. One unit increase in income leads to 0.64 unit increase in imports demand its mean then both have positive relation so when the income of the people will increases it effect the imports. The relations of relative price of imports with imports are as 1 unit increase in relative price of import will decrease 0.22 units in imports. According to economic theory, like savings, consumption and imports are also a positive and increasing function of income. Increase in real exchange rate (appreciation of the domestic currency) leads to increase in imports as these become cheaper from consumer point of view. These results are consistent with other studies (Khan 1974 and Afzal 2001a among other). Population coefficient is unexpected, negative but insignificant. However, since Durbin Watson is extremely low, the results are not valid from standard econometrics theory because Ordinary Least Square results are not efficient that makes validity of $t$ and $F$ test misleading. Therefore the above results are interpreted with great caution.

Table 4.2 OLS Results Export Function:

\begin{tabular}{|l|l|l|l|l|}
\hline Variable & Coefficient & Std.error & t-statistic & p-value \\
\hline Constant & -5.438445 & 1.615257 & -3.366923 & 0.0016 \\
\hline Ln unit value of relative price & -0.266644 & 0.098997 & 2.693451 & 0.0099 \\
\hline Ln real exchange rate & 0.055943 & 0.176604 & 0.316770 & 0.7529 \\
\hline Ln US income & 1.738993 & 0.277361 & 6.269773 & 0.0000 \\
\hline Lnconsumer price index & 0.547680 & 0.234717 & 2.333367 & 0.0242 \\
\hline D0 & 0.141155 & 0.153919 & 0.917070 & 0.3640 \\
\hline AR(1) & 0.477183 & 0.152776 & 3.123407 & 0.0031 \\
\hline
\end{tabular}

$\mathrm{R}^{2}=0.99$ Durbin-Watson $=1.65$, F-statistic: $23002(0.000)$

Exports function results have been shown in Table 4.2. The signs of the relative price variable and the US income are correct and significant. The results are in favour with Afzal (2001b) and Khan (1974). Consumer Price 
Index has an expected sign and is significant. The rise in inflation leads to depreciation of exchange rate and depreciation is expected to promote exports. Afzal and Sijjad (2006) have concluded that depreciation of both nominal and real exchange rates has expansionary effect on the exports supply. That Implies increased demand for exports.

An increase in the real exchange rate or a real depreciation means that foreign prices of goods in rupee (Pakistan's currency) have increased relative to prices of domestically produced goods. This implies that foreign goods (imports) become more expensive compared to goods at home while the domestic goods become cheaper for the foreign countries. Therefore, correct and expected sign of the coefficient of real exchange rate is positive. The liberalization dummy is positive but insignificant. This suggests that liberalization does not have harmful effects on exports. However, because of low Durbin Watson, the results are interpreted with care. The significant F-statistic in both estimations reveals that the underlying variables are all important.

\section{a. ADF Results}

Empirical work based on time series data assumes that the underlying time series is stationary. In regressing a time series variable on another time series variable one can get a very high $\mathrm{R}^{2}$ though there is no meaningful relationship between the two. This situation shows a Spurious Regression that arises in the presence of non-stationary variables. Therefore examination of stationarity/non-stationarity is important before doing any empirical work which is closely linked to the tests for unit roots. Several tests of non-stationarity called unit root tests have been developed in the time series econometrics literature. This study uses ADF unit roots test whose results have been reported in Table 4.3and Table 4.4. If the non-stationarity hypothesis is rejected then the traditional econometrics methods can be used. If not, the theory of cointegration may provide useful information about the relationship between the variables. The theory of cointegration attempts to study the interrelationships between long-run movements in economic time series. The cointegration results have been shown in Tables 4.5 and Tables 4.6.

Table 4.3ADF Results: Imports

\begin{tabular}{|c|c|c|c|c|c|}
\hline $\begin{array}{l}\text { Variables } \\
(\log )\end{array}$ & $\begin{array}{l}\text { Level } \\
\text { Trend } \\
\text { Intercept }\end{array}$ & Probability & $\begin{array}{l}\text { First Difference Trend and } \\
\text { intercept }\end{array}$ & Probability & Result \\
\hline IM & -0.72 & $(0.8383)$ & -5.507 & $(0.0001)$ & $\mathrm{I}(1)$ \\
\hline $\mathrm{Y}$ & -1.84 & $(0.67)$ & -6.62 & $(0.000)$ & $\mathrm{I}(1)$ \\
\hline UVMp & -2.26 & $(0.4428)$ & -6.38 & $(.0 .000)$ & $\mathrm{I}(1)$ \\
\hline WPI & -3.57 & $(0.1422)$ & -4.38 & $(0.005)$ & $\mathrm{I}(1)$ \\
\hline REX & -2.52 & $(0.3177)$ & -2.70 & $(0.08)$ & $\mathrm{I}(1)$ \\
\hline UVMp/WPI & -2.17 & $(0.4928)$ & -6.68 & $(0.000)$ & $\mathrm{I}(1)$ \\
\hline Population & -2.3 & $(0.1551)$ & -1.004 & $(0.2779)$ & $\mathrm{I}(0)$ \\
\hline
\end{tabular}

Note: Test critical values for $1 \%, 5 \%$ and $10 \%$ respectively for with trend and intercept are $-4.26,-3.55$ and -3.20 and the figures in parentheses are MacKinnon (1996) one-sided p-values.

Table 4.3 shows the ADF test results in level and first difference forms. In level form mixed results have been obtained. Rest of the variables corresponding p-values are insignificant therefore leading to the acceptance of the unit root hypothesis. Consequently in level form most of the variables are stationary or I (0).

Table 4.4ADF Results: Exports

Theses ADF results show for the exports.

\begin{tabular}{|l|l|l|l|l|l|}
\hline Variables (log) & $\begin{array}{l}\text { Level } \\
\text { Trend } \\
\text { Intercept }\end{array}$ & probablity & $\begin{array}{l}\text { FirstDifference Trend and } \\
\text { intercept }\end{array}$ & Probability & Result \\
\hline EX & -0.96 & $(0.9384)$ & -4.55 & $(0.004)$ & $\mathrm{I}(1)$ \\
\hline REX & -2.52 & $(0.3177)$ & -2.70 & $(0.08)$ & $\mathrm{I}(1)$ \\
\hline UVXp/UVX & -3.06 & $(0.17)$ & -6.75 & $(0.000)$ & $\mathrm{I}(1)$ \\
\hline CPI & -0.14 & $(0.93)$ & -3.4 & $(0.05)$ & $\mathrm{I}(1)$ \\
\hline USy & -2.80 & $(1.30)$ & -3.51 & $(0.01)$ & $\mathrm{I}(1)$ \\
\hline UVXp=PXd & -2.69 & $(0.2521)$ & -6.26 & $(0.000)$ & $\mathrm{I}(1)$ \\
\hline XW=UVX & -2.47 & $(0.3376)$ & -4.25 & $(0.0013)$ & $\mathrm{I}(1)$ \\
\hline
\end{tabular}

Note: Test critical values for $1 \%, 5 \%$ and $10 \%$ respectively for with trend and intercept, and the figures in parentheses are MacKinnon (1996) one-sided p-values

Table 4.3 and Table 4.4 show the ADF test results in first difference forms. In level form mixed results have been obtained .Except UVXp/UVX USA rest of the variables corresponding p-values are insignificant therefore leading to the acceptance of the unit root hypothesis. Consequently in level form most of the variables are stationary or I (0).

However, in first difference all p-values are highly significant implying that the $\mathrm{H}_{0}$ : the first difference of an underlying variable has a unit root has been rejected for all the six variables listed in the Tables 5.1 and 5.2. This 
means that the first difference is stationary and hence the variables possess unit root in level form. Therefore these variables are non-stationary or I(1).

\section{Cointegration}

A cointegration test is used for to find long run equilibrium relationship exists between time series variables; Johansen (1988) maximum likelihood approach is readily used. Johansen mentions two likelihood ratio tests, the reduced rank of the matrix: the trace test and maximum Eigen value test i.e.

Table 4.5: Imports Function: Inim, Iny, Inpm, Inresx

\begin{tabular}{|l|l|l|l|l|l|l|}
\hline Lag & LogL & LR & FPE & AIC & SC & HQ \\
\hline 0 & 21.69959 & NA & $3.48 \mathrm{e}-07$ & -0.681616 & -0.488573 & -0.608376 \\
\hline 1 & 400.8166 & 665.3891 & $1.85 \mathrm{e}-13$ & $-15.13537^{*}$ & $-13.97712^{*}$ & $-14.69593^{*}$ \\
\hline 2 & 427.0449 & $40.68056^{*}$ & $1.82 \mathrm{e}-13^{*}$ & -15.18551 & -13.06203 & -14.37986 \\
\hline 3 & 452.8621 & 34.77419 & $1.91 \mathrm{e}-13$ & -15.21886 & -12.13017 & -14.04702 \\
\hline 4 & 471.8152 & 21.66068 & $2.91 \mathrm{e}-13$ & -14.97205 & -10.91815 & -13.43400 \\
\hline
\end{tabular}

* indicates lag order selected by the criterion

LR: sequential modified LR test statistic (each test at 5\% level)

FPE: Final prediction error

AIC: Akaike information criterion

SC: Schwarz information criterion

HQ: Hannan-Quinn information criterion

That test is used for the lag length of the data is one as it is an annual data

Table 4.6: Exports Function:

\begin{tabular}{|l|l|l|l|l|l|l|}
\hline Lag & LogL & LR & FPE & AIC & SC & HQ \\
\hline 0 & -29.36867 & NA & $1.71 \mathrm{e}-07$ & 1.443619 & 1.675271 & 1.531508 \\
\hline 1 & 395.1142 & $727.6849^{*}$ & $2.24 \mathrm{e}-14^{*}$ & -14.41282 & $-12.79126^{*}$ & $-13.79761^{*}$ \\
\hline 2 & 428.4385 & 48.96640 & $2.67 \mathrm{e}-14$ & -14.30361 & -11.29214 & -13.16107 \\
\hline 3 & 457.0195 & 34.99715 & $4.33 \mathrm{e}-14$ & -14.00080 & -9.599420 & -12.33092 \\
\hline 4 & 504.9856 & 46.98720 & $3.87 \mathrm{e}-14$ & $14.48921^{*}$ & -8.697923 & -12.29200 \\
\hline
\end{tabular}

* indicates lag order selected by the criterion

LR: sequential modified LR test statistic (each test at 5\% level)

FPE: Final prediction error

AIC: Akaike information criterion

SC: Schwarz information criterion

HQ: Hannan-Quinn information criterion

Before deciding on cointegration, it is desirable that the lag length of the variables is decided on the basis of information criteria. The same has been reported in Table 4.5 and Table 5.6. The lag supported by the criteria though differs is one since the annual data are used. The cointegration results have been shown in Tables $(4.7,4.8$, 4.9 and 4.10).

Table 4.7 Cointegration Rank Test (Trace) Import function: Inim Iny Inpm Inrex

\begin{tabular}{|l|l|l|l|l|}
\hline $\begin{array}{l}\text { Hypothesized } \\
\text { No. of CE(s) }\end{array}$ & Eigenvalue & Trace Statistic & 0.05 Critical Value & Prob. ${ }^{* *}$ \\
\hline None ${ }^{*}$ & 0.355112 & 51.38668 & 47.85613 & 0.0224 \\
\hline At most 1 & 0.254215 & 29.01409 & 29.79707 & 0.6014 \\
\hline At most 2 & 0.200306 & 14.05489 & 15.49471 & 0.8214 \\
\hline At most 3 & 0.050728 & 2.655043 & 3.841466 & 0.1032 \\
\hline
\end{tabular}

Trace test indicates 1 cointegrating eqn(s) at the 0.05 level

$*$ denotes rejection of the hypothesis at the 0.05 level

**MacKinnon-Haug-Michelis (1999) p-values

Table 4.8 Cointegration Rank Test (Eigenvalue) Import function: Inim Iny Inpm Inrex

\begin{tabular}{|l|l|l|l|l|}
\hline $\begin{array}{l}\text { Hypothesized } \\
\text { No. of CE(s) }\end{array}$ & Eigenvalue & Max-Eigen Statistic & 0.05 Critical Value & Prob.** \\
\hline None $*$ & $0.345112^{*}$ & 40.37259 & 37.58434 & 0.05019 \\
\hline At most 1 & 0.254215 & 14.95919 & 21.13162 & 0.2918 \\
\hline At most 2 & 0.200306 & 11.39985 & 14.26460 & 0.1353 \\
\hline At most 3 & 0.050728 & 2.655043 & 3.841466 & 0.1032 \\
\hline
\end{tabular}

Max-eigenvalue test indicates no cointegration at the 0.05 level

* denotes rejection of the hypothesis at the 0.05 level

**MacKinnon-Haug-Michelis (1999) p-values 
In the cointegration Rank test (Eigen and Trace) the null hypothesis is rejected because there is one cointegration vector in the import function.

Table 4.9 Table Cointegration Rank Test (Trace) Exports Function: Inex Inpu Inrex Inusy lncpi

\begin{tabular}{|l|l|l|l|l|}
\hline $\begin{array}{l}\text { Hypothesized } \\
\text { No. of CE(s) }\end{array}$ & Eigenvalue & Trace Statistic & 0.05 Critical Value & Prob. ${ }^{* *}$ \\
\hline None $*$ & 0.577318 & 119.4669 & 69.81889 & 0.0000 \\
\hline At most 1 & 0.461042 & 40.54898 & 47.85613 & 0.16000 \\
\hline At most 2 & 0.348199 & 25.02501 & 29.79707 & 0.13006 \\
\hline At most 3 & 0.337920 & 12.19615 & 15.49471 & 0.2824 \\
\hline
\end{tabular}

Trace test indicates 1 cointegrating eqn(s) at the 0.05 level

* denotes rejection of the hypothesis at the 0.05 level

Table 4.10 Cointegration Rank Test (Eigenvalue) Exports Function Inex Inpu Inrex Inusy Incpi

\begin{tabular}{|l|l|l|l|l|}
\hline $\begin{array}{l}\text { Hypothesized } \\
\text { No. of CE(s) }\end{array}$ & Eigenvalue & Max-Eigen Statistic & 0.05 Critical Value & Prob. ${ }^{* *}$ \\
\hline None ${ }^{*}$ & 0.577318 & 43.91795 & 33.87687 & 0.0023 \\
\hline At most 1 & 0.461042 & 26.52398 & 27.58434 & 0.1048 \\
\hline At most 2 & 0.348199 & 20.82885 & 21.13162 & 0.3299 \\
\hline At most 3 & 0.337920 & 13.03082 & 14.26460 & 0.1357 \\
\hline AT most 4 & 0.022591 & 1.165330 & 3.841466 & 0.2804 \\
\hline & & & & \\
\hline
\end{tabular}

Max-eigenvalue test indicates no cointegration at the 0.05 level

* denotes rejection of the hypothesis at the 0.05 level

**MacKinnon-Haug-Michelis (1999) p-values

The null hypothesis of no cointegration is rejected on the basis of both $\lambda$-max and $\lambda$-trace tests. The cointegration results (Table 4.7 - 5.10) show that there is one cointegrating vector in the both import functions and exports function. Since the purpose is to estimate long-run export and import elasticity, the cointegrating vectors are normalized following the common practice on the import in the imports function and on the ln export in the exports function. Although much normalization is possible, economists usually find that the interpretation of the cointegrating vectors suggests that one of the coefficients in each vector should be set equal to 1 (Afzal 2004a).

Table 4.11 Cointegrating Vectors Normalised on lnm

\begin{tabular}{|l|l|l|l|}
\hline $\ln m$ & $\ln y$ & $\ln$ (uvmp/wpip) & lnrex \\
\hline 1.00 & 1.75 & -2.26 & -1.27 \\
$(8.02)^{*}$ & $(9.56)^{*}$ & $(6.26)^{*}$ & $(7.14)^{*}$ \\
\hline
\end{tabular}

Table 4.12 Cointegrating Vectors Normalized on Inex

\begin{tabular}{|l|l|l|l|}
\hline $\ln e x$ & $\ln U S y$ & $\ln \left(\mathrm{UVXp} / \mathrm{UVX}_{\mathrm{US}}\right)$ & $\ln \mathrm{Rex}$ \\
\hline 1.0 & 3.20 & -2.80 & 0.03 \\
$(10.40)^{*}$ & $(5.60)^{*}$ & $(4.75)^{*}$ & $(6.36)^{*}$ \\
\hline
\end{tabular}

*Note: Chi-square critical values for one and two degrees of freedom are 3.84 and 5.99 respectively.

Tables 4.11 and Table 4.12 reveal that import and export elasticities are adequately high and in absolute terms they add up to more than unity as Marshal Lerner condition postulates. Marshall-Lerner condition deals with the long-run trade elasticities. The estimation of these elasticities based on cointegration technique that explore the long-run relationship among economic variables, supports the Marshall- Lerner condition that suggest that the devaluation is supposed to improve the trade balance in Pakistan in the long-run.

Afzal (2004) argues that the satisfaction of ML condition is not a enough for successful devaluation because it has both microeconomic and macroeconomic aspects. The main objective of devaluation is to change relative prices in a way that will promote exports and discourage imports. From microeconomic perspective, the success of devaluation depends on how elastic imports and exports demand are? If both elasticities are higher, the success of devaluation has better prospects. If elasticities are extremely low, devaluation can worsen the trade balance. The satisfaction of ML condition implies that both elasticities are quite adequate.

He adds that given that ML condition is satisfied, it is relevant to ask why the balance of payments continues to deteriorate after devaluation. A possible explanation is that expansionary monetary policy following the devaluation may be partly responsible for the worsening of the Balance of payments. Devaluation may fail not because of microeconomic issues but because of macroeconomic effects. 


\section{Conclusion}

The test conducted in that research, estimation of elasticity show that the Marshal Lerner condition existence in the Pakistan. The data support the Marshal Lerner condition, and the dependence on imports appears to be the huge factor in trade deficit. Coefficients have correct and expected signs, of the imports relative price, domestic income, real exchange rate remain positive and significant where 1 unit increase in the income leads to 0.64 unit rise in the demand of import, because due to increase in income the foreign goods will be cheaper as consumer point of view so the demand of import will increase. In the export function the findings of the variable like relative price and the USA income remain significant, because when increase in the USA income then export from Pakistani goods increases. We know that the USA is a very big exporter of Pakistan so that's why increase in USA domestic income will also increase's the export from Pakistan. Here CPI has positive sign which is significant also. The rise in inflation leads to exchange rate depreciation but with the depreciation there is increase in export because both nominal and real exchange rate has expansionary effects on the exports supply, which means demand for exports increases .Due to relative prices of domestically production increase which means that domestic production increase, and domestic goods became cheaper for the foreign countries .So real exchange rate have positive sign and liberalization used in that study which is measured by the pre time of devaluation and after devaluation effect which is a dummy variable means it cannot influence the exports of the Pakistan. Cointegration is used to find out the long run connection, so economic variables were used to evaluate the long-run Marshall-Lerner condition.

The cointegration approach is supportive for the Marshall-Lerner condition. This suggests that depreciation of currency must improve the Pakistan trade balance. But even though, the trade balance does not increase significantly. Studies vary in their results. Many studies have testified that devaluation would recover balance of trade in developing countries and it is expansionary; but the other studies concluded that devaluation is contractionary and will not improve balance of trade. Though, devaluation is a significant macroeconomic policy that could be used complemented by appropriate monetary and fiscal policies to steady the economy.

\section{References}

- Aftab Z, and Khan S. (2008). Bilateral J-Curves between Pakistan and Her Trading Partners PIDE Working Papers 2008:45

- Afzal, M (2011), Impact of Exchange Rate Depreciation on Domestic Output in Pakistan, Business Review, 6(2), 80-89

- Afzal, M. \& Ejaz Hussain (2010). Export-led Growth Hypothesis: Evidence from Pakistan (1990 -2008), Indian Journal of Quantitative

- Afzal, M. (2001a). Import Functions for Pakistan - A Simultaneous Equation Approach, The Lahore Journal of Economics, 6(2), 109-116

- Afzal, M. (2004a). Estimating Long - Run Trade Elasticities in Pakistan: Cointegration

- Afzal, M. (2007). Savings and Investment in Developing Countries: Causality Test, Philippine Review of Economics, 44(2), 99-110

- Afzal, M. (2008). Impact of Exchange Rate on Import Demand in Pakistan, Pakistan Journal of Applied Economics, 18 (1\&2), 123-141

- Afzal, M. (2010). Exchange Rates \& Reserves in Asian Countries: Causality Test, Global Economic Review, $39(2), 215-223$

- Afzal,M. (2001b). Exports in a Simultaneous Model - The Case of Pakistan, Government College, Economic Journal, 35(1\&2), $53-66$

- Afzal,M. (2004b). Exports-Economic Growth Nexus: Pakistan's Experience, Indian Journal of Business and Economics, 3 (2), 315-340

- Ahmed E, and Majeed T M, (2006). Determinants of Exports in Developing Countries, The Pakistan Development Review 45 : 4 Part II (Winter 2006) pp. 1265-1276

- Arize, A. (1986). The Supply and Demand for Imports and Export in a Simultaneous Model. Pakistan Economic and Social Review 24:2, 51-16.

- Arize. (2002). Imports and exports in 50 countries test of cointegration and structural breaks international review of economics and finance, 11 (2002) 101-115

- Aurangzeb and Aftab Z. (2002). The Long-run and Short-run Impact of Exchange Rate Devaluation on Pakistan's Trade, The Pakistan Development Review 41: 3 (Autumn 2002) pp. 277-286

- Bahmani-Oskooee,M and Satawatananon K. The Impact of Exchange Rate Volatility on Commodity Trade between the U.S. and Thailand

- Eita (2013). Estimation of the Marshall-Lerner Condition for Namibia, International Business \& Economics Research Journal - May 2013 Volume 12, Number

- Enders Walter (2004), Applied Econometric Time Series, $2^{\text {nd }}$ Ed, John Wiley and Sons

- Goldstein, M. and Khan, M. (1985), Income and price effects in foreign trade in R.W. Jones and P.B. Kenen (eds.), Handbook of International Economics, North-Holland, Amsterdam, 1041-1105. 
- Government of Pakistan, Economic Survey (various issues) Islamabad, Ministry of Finance, Economic Advisor Wing

- Gujarati, Damodar N and Sangeetha (2007), Basic Economics, 4/1atest Ed, Tata McGraw-Hill Inc

- Hasan, M. Aynul, and A. H. Khan (1994) Impact of Devaluation on Pakistan's External Trade: An Econometric Approach. The Pakistan Development Review 33:4, 1205-1215.

- Hirschman, A. (1949). Devaluation and the Trade Balance: A Note, The Review of Economics and Statistics, 31(1): 50-53

- IMF (Various Issues) International Financial Statistics. Washington, D. C.: IMF.

- Jamilov R. J-Curve dynamics and the Marshall-Lerner condition: evidence from keniya.

- Johansen, S. (1991), Estimation and Hypothesis Testing of Cointegrating Vectors in Gaussian Vector Autoregressive Models, Econometrica, 59, 1551-1580

- Johansen, S. (1995), Likelihood-based inference in Cointegrated Vector Autoregressive Models,

- Khan, Kakar M K., Kakar R, and Waliullah (2010). The Determinants of Pakistan's Trade Balance: An ARDL Cointegration Approach, The Lahore Journal of Economics 15: 1 (Summer 2010): pp. 1-26

- Khan, M. (1974), Import and export demand in developing countries, IMF Staff Papers, 21, 678-693. .

- Lai, K and Lowinger C (2002), The J-Curve: Evidence from East Asia , Journal of Economic Integration 17(2), 397-415 Ling Y. N and Mun W.H. Real Exchange Rate and Trade Balance

- Mackinnon, James G., Alfred A. Haug, and L. Michelis (1999). Numerical Distribution Functions: Likelihood Ratio Tests for Cointegration. Journal of Applied Econometrics 14, 563-577.7

- Pandey R. (2013). Trade Elasticity's and the Marshal Lerner Condition for India, Global Journal of Management and Business Studies. ISSN 2248-9878 Volume 3, Number 4 (2013), pp. 423-428

- Relationship: An Empirical Study on Malaysia, International Journal of Business and Management Vol. 3, No. 8

- Robinson, J. (1937). Essays in the Theory of Employment, New York: Macmillan Company. Economics, 8(1), 130-147

- Robinson, J. (1947). Essays in the Theory of Employment. Oxford: Basil Blackwell.

- Sek K S, and Her M W, (2014). Testing the Marshal-lerner Condition: Bilateral trades between Malaysia and trading partners, Journal of Advanced Management Science, Vol. 2, No. 1, pp. 23-28, March 2014. doi: 10.12720/joams.2.1.23-28

- The Pakistan Development Review, Vol. 39, No. 1 (Spring 2000), pp. 37-50 